\title{
HPV positive oropharyngeal cancer: risky sexual behavior
}

\author{
Câncer de orofaringe HPV positivo: comportamentos sexuais de risco
}

\section{Denise Costa Oliveira1, Rafael Prado dos Santos ${ }^{1}$, Flávio Carneiro Hojaij ${ }^{2}$}

Oliveira DC, Santos RP, Hojaij FC. HPV positive oropharyngeal cancer: risky sexual behavior / Câncer de orofaringe HPV positivo: comportamentos sexuais de risco. Rev Med (São Paulo). 2018 jan.-fev.;97(1):98-102.

ABSTRACT: Oropharyngeal squamous cell carcinomas have traditionally been associated with tobacco and alcohol use. Although smoking rates had been decreasing, there is an increase in the incidence of Oropharyngeal squamous cell carcinomas in the last years. This increase of Oropharyngeal squamous cell carcinomas is noticed in one specific type, Oropharyngeal squamous cell carcinomas associated with human papillomavirus (HPV) infection, mainly the HPV16 type, a high-risk HPV. Transmission of HPV is known as occur through sexual contact but many researches differ on which kind of sexual contact is the responsible for the HPV infection. Objective: The objective of this review is to verify in the literature if there is a pattern of sexual behavior that is more related with oropharyngeal squamous cell carcinoma HPV positive. The habits most associated with Oropharyngeal squamous cell carcinomas are oral sex and multiples sexual partners. The occurrence of this habits in the population varies from local culture, social status and ethnic group. In this context, health care professionals have a major responsibility in orientating about aspects of the disease, risk factors, vaccination and prognosis. Further researches are necessary to clarify the role of vaccination for HPV in future changes in the Oropharyngeal squamous cell carcinomas prevalence.

Keywords: Oropharyngeal cancer; Papillomaviridae; Sexual behavior; Carcionma, squamous cell.
RESUMO: O carcinoma de células escamosas de orofaringe é tradicionamente associado com uso de tabaco e álcool. Apesar da prevalência de tabagistas ter diminuído, a prevalência de carcinoma de células escamosas de orofaringe vem aumentando. Esse aumento do carcinoma de células escamosas de orofaringe pode ser notado em um tipo específico, o associado com infecção pelo papilomavirus humano (HPV), principalmente o HPV 16, um subtipo de HPV de alto risco. A transmissão do HPV é conhecidamente por contato sexual, mas muitas pesquisas diferem quanto ao tipo de contato responsável pela infecção pelo HPV. Objetivo: O objetivo dessa revisão é verificar se existe na literatura um padrão de comportamento sexual que está mais relacionado com o câncer de orofaringe HPV positivo. Os hábitos mais associados com carcinoma de células escamosas de orofaringe são realização de sexo oral e múltiplos parceiros sexuais. A ocorrência desses hábitos na população variam conforme a cultura local, nível social e grupos étnicos. Nesse contexto, profissionais de saúde têm grande responsabilidade na orientação sobre aspectos da doença, fatores de risco, vacinação e prognósticos. Outras pesquisas ainda são necessárias para determinar qual é o papel da vacinação contra HPV em futuras mudanças na prevalência do carcinoma de células escamosas de orofaringe.

Descritores: Neoplasias orofaríngeas; Papillomaviridae; Comportamento sexual; Carcinoma de células escamosas.

Artigo desenvolvido na Disciplina Optativa "Abordagem Prática da Escrita Científica” sob coordenação da Revista de Medicina do DC-FMUSP.

1. Faculdade de Medicina FMUSP, Universidade de São Paulo, São Paulo, SP, BR. Acadêmicos de Medicina da FMUSP. Emails: denise. oliveira@fm.usp.br, http://orcid.org/0000-0002-9710-6105; pradorafael20@gmail.com, http://orcid.org/0000-0002-7049-3854.

2. Faculdade de Medicina FMUSP, Universidade de São Paulo, São Paulo, SP, BR. Médico, Livre-docente do LIM-02 do HCFMUSP. Email: fchojaij@uol.com.br; https://orcid.org/0000-0003-0080-022X.

Endereço para correspondência: Flávio C. Hojaij. Rua Pe. João Manoel, 450. São Paulo, SP, BR. CEP: 01411-001. 


\section{INTRODUCTION}

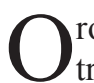
ropharyngeal squamous cell carcinoma has traditionally been associated with tobacco and alcohol use. Although smoking rates had been decreasing, there is an increase in the incidence of this kind of squamous cell carcinoma in this last years ${ }^{1}$. Recent studies suggest some of those Oropharyngeal squamous cell carcinomas are associated with human papillomavirus (HPV) infection, mainly the HPV16 type, a high-risk HPV. Transmission of HPV is known to occur through sexual contact and oralgenital contact may lead to oropharyngeal HPV infection. In this review, we discuss the relation between oropharyngeal squamous cell carcinomas and risky sexual behavior as well as the role of health care practitioners to stop this epidemic.

\section{a) HPV}

Human papillomavirus is a double-stranded, circular, DNA virus, with tropism for mucosal or cutaneous squamous surfaces, in which infects basal keratinocytes ${ }^{2}$. In fact, exposure to HPV occurs with high incidence and lifetime prevalence is higher than $43-62 \%{ }^{3}$. Transmission happen by sexual contact, primarily, or less intimate skin-to- skin contact. Infections by high-risk HPV are asymptomatic and majority persons usually will clear viremia and never develop carcinoma induced by virus ${ }^{4}$.

There are more than 120 described subtypes of HPV and some of those are linked with a high-risk to develop into cancer (i.e.: HPV-16 and HPV-18) s. Viral $^{5}$ DNA encodes eight major proteins and when high-risk HPV DNA integrates the human keratinocytes nuclear DNA there are an expression of oncogenic proteins, E6 e E7. In this process, E6 binds to the p53 gene tumor-suppressor proteins and $\mathrm{E} 7$ binds to $\mathrm{pRB}$ (retinoblastoma protein) leading to malignant mutations in these cells ${ }^{6}$.

\section{b) HPV and neoplasms}

High-risk HPV infection is a well-established risk factor for cervical cancer. More than $90 \%$ of uterine cervical carcinoma are due to HPV infection ${ }^{7}$. Recently, HPV infection have been linked with a higher risk to develop oropharyngeal squamous cell carcinomas. Studies suggests that HPV is the main responsible for the increasing incidence of oropharyngeal squamous cell carcinomas even with decreasing tobacco consumption ${ }^{1}$.

\section{c) HPV and oropharyngeal neoplasms}

The oropharynx is a part of pharynx delimited proximally by the posterior edge of the hard palate and distally by the vallecula and hyoid bone. The oropharynx is divided in four subsites: posterior pharyngeal wall, soft palate, tonsillar complex and base of the tongue. Cancer in each of these subsites has different implications in clinical presentation and treatment approach ${ }^{8}$.
Tobacco and alcohol are known as the major risk factors for oropharyngeal squamous cell carcinomas. With decreasing tobacco consumption, it was expected a drop in the incidence of oropharyngeal squamous cell carcinomas. However, this type of cancer has shown a stagnation in number of new diagnosed cases. Notwithstanding, oropharyngeal squamous cell carcinomas has shown an increasing incidence among younger population. ${ }^{(1)}$ For these reasons, HPV emerged as an interesting subject of study in oropharyngeal squamous cell carcinomas field. HPV related oropharyngeal squamous cell carcinomas have been showing a better prognosis if compared with those related to tobacco and alcoholism ${ }^{9,10}$. This fact makes stratification necessary for studies involving oropharyngeal squamous cell carcinomas. The exponential increase in incidence of this type of cancer makes necessary actions to stop this picture. Health care practitioners plays a key role in this process, giving information to patients about a disease that remains unknown for the majority of the population.

To attend this objective, its essential a knowledge of the principal risk factors for the development of the disease. Our review of literature focuses on sexual behavior and its association with oropharyngeal squamous cell carcinomas development.

\section{OBJECTIVE}

The objective of this review is to verify in the literature if there is a pattern of sexual behavior that is more related with oropharyngeal squamous cell carcinoma HPV positive.

\section{METHODS}

In order to organize the informations about Oropharyngeal neoplasms, there relation with HPV and the possibility to use the HPV infection as a marker of sexual behavior, we did a simple review of the literature using the PubMed database. The search terms used was "oropharyngeal cancer" and "HPV" and "human papillomavirus" and "sexual behavior". We also filter our research using articles published in the last 6 years because that was the first article we found about sexual behaviors and oropharyngeal cancer HPV positive, in english or portuguese and that preferably full text was available in the database. Using these terms and filters we found 15 articles, the oldest was published in 2011 and the newest in 2016.

To complement the initial research, we include some articles used as references in the literature review articles we found in the original research ${ }^{2,4,6,7}$. This complement articles were used to elucidate some concepts, for example the definition of oropharyngeal squamous cell carcinoma or general information about HPV. 


\section{RESULTS}

In our research we identify 15 articles focused on HPV associated oropharyngeal cancer and sexual behavior as a risk factor ${ }^{1,3,9,11-22}$. One article studied the knowledge of HPV and its association with oropharyngeal cancer in a high-risk population ${ }^{16}$. One article doesn't discuss the relation of Oropharyngeal cancer HPV+ with sexual behavior $^{15}$. Two articles affirm that sexual behavior can't be used as sexual behavior marker. One affirm that since socioeconomic status and education are aspects that determine the sexual behavior this have implications for prevention efforts, including tobacco cessation, general behavior modification, and vaccination programs ${ }^{3}$. The other affirms that the HPV has influence in the oropharyngeal cancer depending on its viral load and stage and that's not determined by demographic or behavioral factors ${ }^{14}$. The other ten articles affirm the HPV can be used as sexual behavior marker, 11-13,17-22, but each article used a different aspect of sexual behavior to establish that.

The many aspects of sexual behavior used to determine if it can be used as a marker was number of sexual partners ${ }^{3,16,17,19,21,22}$, practicing oral-genital $\operatorname{sex}^{18,20}$, number of oral-genital sex partners ${ }^{3,11,12,22}$, practicing oral-anal $\operatorname{sex}^{20}$, age of first sexual interaction ${ }^{16,17}$, age of first oral-genital sexual interaction ${ }^{17}$, perception of risk of sexually transmitted disease ${ }^{(16)}$ and marital status ${ }^{9}$.

\section{DISCUSSION}

HPV is in the center of attentions of oropharyngeal squamous cell carcinomas. Chaturverdi et al. ${ }^{1}$ shown a HPV prevalence increasing from 16.3\% during 1984 to 1989 to $71.7 \%$ during 2000 to 2004 and estimated that, if the incidence trend continue, the annual number of HPVpositive oropharyngeal cancers is expected to surpass the annual number of cervical cancers by the year 2020 . In Latin America, Brazil, included, has a high incidence of oropharyngeal squamous cell carcinomas among both $\operatorname{sex}^{23}$ and specifically in Brazil, more than two thirds of the oropharyngeal squamous cell carcinomas are diagnosed at late stage of the disease ${ }^{24}$ and the survival rate for oral and oropharyngeal cancer in 5 -years is less than $50 \%{ }^{25}$. The Human papillomavirus (HPV) type 16 was recognize by the International Agency for Research on Cancer as the only type of HPV that is carcinogenic to organs other than the cervix uteri, such as oral cavity oropharynx, tonsil, vulva, vagina, penis and anus ${ }^{26}$. In comparison with HPV negative tumors, HPV positive oropharyngeal squamous cell carcinomas have been associated with a better prognosis ${ }^{9,10,27}$, lesser history of tobacco and alcohol use ${ }^{28}$, higher socioeconomic status ${ }^{3}$, younger age on diagnosis and been more common in men and whites ${ }^{17}$ among the world. In Brazil, the HPV 16 positive in tumor tissue was higher in women and patients with 50 years old or younger ${ }^{27}$. Sexual behavior is the most studied risk factor for the development of this tumor, but there is no concordance about which kind of sexual behavior is risky.

Oral sex is one of more studied factors. Nguyen et al. ${ }^{11}$ showed in there review a great increase in individuals who admitted to having oral sex in America, from 10 to $18 \%$ in 1993 to $88 \%$ to $90 \%$ in 2002 . This change in sexual habits could explain the rise of oropharyngeal squamous cell carcinomas HPV+. Dahlstrom et al. ${ }^{3}$ demonstrated that white males have higher mean number of oral sexual partners than Hispanic and black males and this explains why they have a higher chance to develop oropharyngeal squamous cell carcinomas HPV+. Interestingly, black males reported higher number of life sexual partners, but they had not engaged in oral $\operatorname{sex}^{3}$. This data suggests that number of sexual partners could not be an independent risk factor for the development of oropharyngeal squamous cell carcinomas HPV positive. Sivasithamparam et al. compared HPV negative with HPV positive patients with oropharyngeal squamous cell carcinomas and demonstrated that oropharyngeal squamous cell carcinomas HPV positive patients are more likely to have a higher number of lifetime sexual partners and oral sex partners ${ }^{22}$. However, in this study patients were only classified into two groups: patients who had more than 10 lifetime sexual partners and more than 5 lifetime oral sexual partners; and patients who had less than 10 lifetime sexual partners or less than 5 lifetime oral sexual partners. With this data is impossible to know which sexual behavior is more related with oropharyngeal squamous cell carcinomas development.

D'Souza et al. ${ }^{17}$ shown that whites have a higher number of oral sexual partners and are more likely to perform oral sex at young ages than other ethnicities. When adjusted to sexual behavior, white race and younger age didn't not stand as an important risk factor, suggesting that they are not independent risk factors ${ }^{17}$. However, this study demonstrate that gender remains as an important risk factor even when adjusted with behavioral variable. Others papers had done the same ${ }^{3}$. One hypothesis is that performing oral sex in HPV infected woman increases the chances to be infected with HPV. Some studies that included women who have sex with women (WSW) didn't reach a significant sample to be analyzed ${ }^{3,12}$.

Anderson et al. studied the serologic responses into HPV oropharyngeal squamous cell carcinomas and concluded that there is not a correlation between early serology with number of oral sexual partners. This study also shown that partners of patients with HPV oropharyngeal squamous cell carcinomas don't show a higher serologic response for $\mathrm{IgG}$ antibodies related to HPV-16 infection compared to a control population ${ }^{14}$. This data raises the question of why some people clarify the virus and others don't.

Mouth to mouth kissing has been linked with a higher risk of development of HPV oropharyngeal squamous cell 
carcinomas but more studies are needed to affirm that it is a risk factor ${ }^{20}$.

An interesting question is about the knowledge of the population and how it affects sexual behavior. OsazuwaPeters et al. ${ }^{16}$ studied a population of African Americans who attended to a race event and they had been asked to answer an anonymous questionnaire about HPV. Only $55 \%$ of the population have heard about HPV and only $30 \%$ knew that HPV increases the chance of developing head and neck cancer. Of those who had heard about $\mathrm{HPV}$, only $25 \%$ reported that they get the information from a healthcare practioner ${ }^{16}$. Greely et al. ${ }^{29}$ reported an interesting appointment: in only $6.4 \%$ of men and $5.7 \%$ of women had reported use of condoms at their last oral sexual encounter. After the HIV epidemic, there was an increase in oral-genital sex practices because the general belief that it was safer. The health care practitioners play a major role in informing the patients about the risks and encourage about condom use in oral sex.

Taberna et al. ${ }^{30}$ studied the changes in sexual behavior after a diagnosis of. oropharyngeal squamous cell carcinomas. There was decline in sexual relationships in the 6 months after diagnosis. These changes were independent of tumor HPV status. However, it was common patients with HPV positive tumors blame themselves for the diagnosis or felt guilty to exposing their partner ${ }^{30}$. It is

\section{REFERENCES}

1. Chaturvedi A, Engels E, Pfeiffer R, Hernandez B, Xiao W, Kim E, et al. Human papillomavirus (HPV) and rising oropharyngeal cancer incidence and survival in the United States. J Clin Oncol. 2011;29(15 Suppl):5529. doi: 10.1200/ JCO.2011.36.4596.

2. Tommasino M. The human papillomavirus family and its role in carcinogenesis. Semin Cancer Biol. 2014;26:13-21. doi: 10.1016/j.semcancer.2013.11.002.

3. Dahlstrom K, Bell D, Hanby D, Li G, Wang L, Wei Q, et al. Socioeconomic characteristics of patients with oropharyngeal carcinoma according to tumor HPV status, patient smoking status, and sexual behavior. Oral Oncol. 2015;51(9):832-8. doi: 10.1016/j.oraloncology.2015.06.005.

4. Burd E. Human papillomavirus and cervical cancer. Clin Microbiol Rev. 2003;16(1):1-17. doi: 10.1128/CMR.16.1.117.2003.

5. World Health Organization, Department of Reproductive Health and Research and Department of Chronic Diseases and Health Promotion. Comprehensive cervical cancer control: a guide to essential practice. Geneva; 2006.

6. Munger K, Baldwin A, Edwards K, Hayakawa H, Nguyen $\mathrm{C}$, Owens $\mathrm{M}$, et al. Mechanisms of human papillomavirusinduced oncogenesis. J Virol. 2004;78(21):11451-60. doi: 10.1128/JVI.78.21.11451-11460.2004.

7. Bosch F, Lorincz A, Munoz N, Meijer C, Shah K. The causal relation between human papillomavirus and cervical cancer. J Clin Pathol. 2002;55(4):244-265. Available from: http:// important to clarify with patients that a change in sexual behavior with long-term sexual partners do not decreases chances of HPV infection by the partner ${ }^{17}$.

\section{CONCLUSION}

Although the difficulties in establish which behavior could lead to a HPV infection is possible to affirm that multiples sexual partners and oral sex are the manly risk factors to HPV transmission. These sexual behaviors are still strongly associated local culture, social status and ethnic group but the changes in the sexual behavior through time may cause difference to the HPV infection and variation in the oropharyngeal squamous cell carcinomas prevalence.

Based on the results we found, we would like to infer a recommendation for health care providers to be aware with some types of sexual behavior related with high risky for development of oropharyngeal squamous cell carcinoma HPV positive. Health care providers play a key role in stopping the HPV positive oropharyngeal squamous cell carcinomas epidemic. Patients already diagnosed with this disease, as well as his sexual partner, must be oriented about sexual practice to avoid a decline in the quality of life, since the changes in sexual behavior with fix partners hardly make a difference in the development of the disease.

$$
\text { jcp.bmj.com/content/55/4/244.long. }
$$

8. Hermans R. Neoplasms of the oropharynx. In: Hermans $\mathrm{R}$, editor. Head and neck cancer imaging. Berlin: Springer; 2006 p.129-42. https://doi.org/10.1007/3-540-33066-6_7.

9. Worsham M, Stephen J, Chen K, Mahan M, Schweitzer $\mathrm{V}$, Havard S, et al. Improved survival with HPV among African Americans with oropharyngeal cancer. Clin Cancer Res. 2013;19(9):2486-2492. doi: 10.1158/1078-0432. CCR-12-3003.

10. Ang K, Harris J, Wheeler R, Weber R, Rosenthal D, Nguyen-Tân P, et al. Human papillomavirus and survival of patients with oropharyngeal cancer. N Engl J Med. 2010;363(1):24-35. doi: 10.1056/NEJMoa0912217.

11. Nguyen N, Nguyen L, Thomas S, Hong-Ly B, Chi A, Vos P, et al. Oral sex and oropharyngeal cancer: The role of the primary care physicians. Medicine (Baltimore). 2016;95(28):e4228. doi: 10.1097/MD.0000000000004228.

12. Rettig E, Fakhry C, Rositch A, Burke A, Chang K, Silver M, et al. Race is associated with sexual behaviors and modifies the effect of age on human papillomavirus serostatus among perimenopausal women. Sex Transm Dis. 2016;43(4):231237. doi: $10.1097 /$ OLQ.0000000000000426.

13. Moore K, Mehta V. The growing epidemic of HPV-positive oropharyngeal carcinoma: a clinical review for primary care providers. J Am Board Fam Med. 2015;28(4):498-503. doi: 10.3122/jabfm.2015.04.140301.

14. Anderson K, Gerber J, D'Souza G, Pai S, Cheng $\mathrm{J}$, Alam R, et al. Biologic predictors of serologic responses to HPV in oropharyngeal cancer: the HOTSPOT 
Oliveira DC, et al. HPV positive oropharyngeal cancer: risky sexual behavior.

study. Oral Oncol. 2015;51(8):751-8. doi: 10.1016/j. oraloncology.2015.05.007.

15. DiMaio D. Nuns, warts, viruses, and cancer. Yale J Biol Med. 2015;88(2):127-9. Available from: https://www.ncbi. nlm.nih.gov/pmc/articles/PMC4445434/.

16. Osazuwa-Peters N, Wang D, Namin A, John V, O'Neill M, Patel P, et al. Sexual behavior, HPV knowledge, and association with head and neck cancer among a high-risk group. Oral Oncol. 2015;51(5):452-6. doi: 10.1016/j. oraloncology.2015.01.011.

17. D'Souza G, Cullen K, Bowie J, Thorpe R, Fakhry C. Differences in oral sexual behaviors by gender, age, and race explain observed differences in prevalence of oral human papillomavirus infection. PLoS ONE. 2014;9(1):e86023. doi: 10.1371/journal.pone.0086023.

18. Pytynia K, Dahlstrom K, Sturgis E. Epidemiology of HPV-associated oropharyngeal cancer. Oral Oncol. 2014;50(5):380-6. doi: 10.1016/j.oraloncology.2013.12.019.

19. Colon-López V, Quiñones-Avila V, Del Toro-Mejías L, Reyes K, Rivera M, Nieves K, et al. Oral HPV infection in a clinic-based sample of Hispanic men. BMC Oral Health. 2014;14(1):7. doi: 10.1186/1472-6831-14-7.

20. Fakhry C, D'Souza G. Discussing the diagnosis of HPV-OSCC: common questions and answers. Oral Oncol. 2013;49(9):863-71. doi: 10.1016/j. oraloncology.2013.06.002.

21. Bahl A, Kumar P, Dar L, Mohanti B, Sharma A, Thakar A, et al. Prevalence and trends of human papillomavirus in oropharyngeal cancer in a predominantly north Indian population. Head Neck. 2013;36(4):505-10. doi: 10.1002/ hed.23317.

22. Sivasithamparam J, Visk C, Cohen E, King A. Modifiable risk behaviors in patients with head and neck cancer. Cancer. 2013;119(13):2419-26. doi: 10.1002/cncr.27993.
23. Ferlay J, Shin H, Bray F, Forman D, Mathers C, Parkin D. Estimates of worldwide burden of cancer in 2008: GLOBOCAN 2008. Int J Cancer. 2010;127(12):2893-917. doi: $10.1002 /$ ijc. 25516 .

24. Anantharaman D, Abedi-Ardekani B, Beachler D, Gheit T, Olshan A, Wisniewski K, et al. Geographic heterogeneity in the prevalence of human papillomavirus in head and neck cancer. Int J Cancer. 2017;140(9):1968-75. doi: 10.1002/ ijc.30608.

25. Carvalho A, Ikeda M, Magrin J, Kowalski L. Trends of oral and oropharyngeal cancer survival over five decades in 3267 patients treated in a single institution. Oral Oncology. 2004;40(1):71-6.

26. World Health Organization. International Agency for Research on Cancer (IARC). IARC Monographs on the evaluation of carcinogenic risks to humans, vol. 100: a review of human carcinogens. Lyon, France: International Agency for Research on Cancer; 2011.

27. López R, Levi J, Eluf-Neto J, Koifman R, Koifman S, Curado M, et al. Human papillomavirus (HPV) 16 and the prognosis of head and neck cancer in a geographical region with a low prevalence of HPV infection. Cancer Causes Control. 2014;25(4):461-71.

28. Applebaum K, Furniss C, Zeka A, Posner M, Smith J, Bryan J, et al. Lack of Association of Alcohol and Tobacco with HPV16-Associated Head and Neck Cancer. JNCI J Natl Cancer Inst. 2007;99(23):1801-10. doi: 10.1093/jnci/ $\operatorname{djm} 233$.

29. Greely A, Janus S, Janus C. The Janus report on sexual behavior. Contemporary Sociol. 1994;23(2):221.

30. Taberna M, Inglehart R, Pickard R, Fakhry C, Agrawal A, Katz M, et al. Significant changes in sexual behavior after a diagnosis of human papillomavirus-positive and human papillomavirus-negative oral cancer. Cancer. 2017;123(7):1156-65. doi: 10.1002/cncr.30564. 